\title{
The Problem of Residence in State Taxation of Income
}

\author{
Frank $M$. Keesling*
}

IT Is now well settled that the states may tax not only income from property and activities within their borders, even though derived by nonresidents, ${ }^{1}$ but also the income of residents from extraterritorial sources as well. ${ }^{2}$ This comprehensive jurisdiction to tax gives rise to three questions of paramount importance: first, to what extent should the states exercise their jurisdiction?; second, how may double state taxation of income of residents derived from extraterritorial sources be eliminated?; and third, who should be included in the category of residents taxable on their entire net income, including income from intangibles and income from sources outside the taxing state?

EXTENT TO WHICH STATES SHOULD EXERCISE JURISDICTION TO TAX INCOME OF RESIDENTS AND NJONRESIDENTS

The decisions of the United States Supreme Court upholding the power of the states to tax the entire income of residents, even though derived from sources outside the taxing state, are in harmony with the theory that an income tax is based primarily upon ability to pay. They clear the way for the proper functioning of the progressive rates characteristic of such a tax. If the states avail themselves of the full measure of their jurisdiction, they can levy income taxes which actually measure true net income; namely, the difference between the taxpayer's aggregate gains from ail sources for the taxable year and his aggregate related deductions, and thereby apportion some of the costs of government among their residents according to ability to pay.

*Member of the Los Angeles Bar; A.B. 1928, LI.B. 1931, University of California. Author in collaboration with Roger J. Traynor of Recent Changes in the Bank and Corporation Franchise Tax Act (1933) 21 CAIIF. L. REv. 543, (1934) 22 ibid. at 499, 23 ibid. at 51; and The Scope and Nature of the Califormia Income Tax (1936) 24 ibid. at 493 .

I Sbaffer v. Carter (1920) 252 U. S. 37.

2 New York ex rel. Cobn v. Graves (1937) 300 U.S. 308, upholding the power of a state to tax the income of a resident from land in another state; Lawrence v. State Tax Comm. (1932) 286 U. S. 276, upholding a tax on the income of a resident from activities in another state. 
If the tax is imposed upon anything less than the total net income from all sources, it bears no. real relation to ability to pay. Thus if it were limited to local income, it would coincide with that ability only in the case of residents who derived all of their income from local sources, and were therefore subject to a tax corresponding to their total net income. Other residents having the same total net income, and therefore the same ability to pay, but receiving that income from both local and extraterritorial sources, would pay lower taxes, while those who received all of their income from extraterritorial sources would pay the states of their residence no tax at all. Contrarily, residents whose income from local sources is offset or outweighed by losses elsewhere, and who therefore actually have no net income, would nevertheless be compelled to pay an income tax. The discrimination would be the inore severe_when progressive rates come into operation, for these rates, designed to correspond with the progressive growth in ability to pay, would correspond to such ability only in the case of those residents whose total net income is subject to the tax, and would give an undue advantage to those taxpayers who are taxable on a part only of their net income.

For the same reasons a tax confined to the local income of nonresidents would not be a net income tax, for there would then be even less chance of its bearing much relation to ability to pay. ${ }^{3}$ Yet a state may find ample justification for extending its tax to the local income of nonresidents not subject to a comparable tax elsewhere. Such an extension is essential to the fairness as well as to the effectiveness of the tax on the state's own residents. The complete exemption of nonresidents would give them an advantage, particularly vital in the case of business competition with residents, which would soon operate to discourage residence within the state. Since a state should hesitate to prevent discrimination against nonresidents at the cost of discriminating against its own residents, its logical alternative is to prevent discrimination against either group by extending its tax to the local income of nonresidents.

3 The state could not itself establish such a relation by extending its tax, even if it were constitutionally permissible to do so, to all the income of nonresidents. Such a course would only drive nonresidents to dispose of their property in the state and cease their business activities therein unless they received sufficient income from sources within the state to exceed not only its tax, but also the tax in the states of their residence and the income which could be obtained from investments elsewhere. Even in that event, a state could find little justification for levying on nonresidents, on the basis of their ability to pay, a tax out of all proportion to the privileges, benefits or protection accorded in return. 
If all states imposed income taxes at comparable rates on the entire net income of their residents, there would be no necessity whatever to tax the local income of nonresidents, since that income would then be subject to a burden equivalent to that imposed upon the local income of residents. In the absence of such conditions, however, a state is fully justified in artificially grafting upon its income tax system a tax upon the local income of nonresidents which bears no relation to their total net income.

In this application the tax would not, as in the case of residents, be a personal tax measured by the taxpayer's ability to pay. The incoine tax proper would be based upon the protection accorded by the state to the resident, "in his person, in his right to receive the income, and in his enjoyment of it when received". "As applied to nonresidents, the tax would be based upon the state's jurisdiction over the property, business and activities giving rise to their local income. Despite their dissimilarity, the two bases may coexist without disharmony. Thus, in Shaffer $v$. Carter ${ }^{5}$ the contention that an income tax is a "subjective tax imposing personal liability upon the recipient of the income" and could not, therefore, be imposed upon a nonresident was renounced by the court:

"The personal element cannot, by any fiction, oust the jurisdiction of the State within which the income actually arises and whose authority over it operates in rem."

While the simultaneous use by several states of both bases for the taxation of income may result in double taxation of the same income in those cases where residents of one state derive income from sources in another, no injustice will result if the states adopt some method of equalizing the relatively heavy tax burdens in such cases.

\section{ELIMINATION OF DOUBLE STATE TAXATION OF INCOME}

Discriminatory double taxation of income derived from property and activities in states other than the state of which the recipient is a resident, although reduced in extent, will not be eliminated by confining the taxation of imcome either to income of residents, or to income from sources within the state, unless one or the other of these concepts is followed uniformly. So long as some states tax income

4 Lawrence v. State Tax Comm., supra note 2, at 281.

5 Supra note 1.

6 Ibid. at 54, 55 . 
of residents from sources without the state and other states tax income of nonresidents from sources within the state, income of residents of the former derived from sources within the latter will be double taxed irrespective of whether any of the states follow both concepts.

Most of the states having income tax laws follow both concepts of income taxation and thus tax not only income from sources within the state irrespective of the residence of the recipient, but also tax persons classed as residents on income from extraterritorial sources as well. Although each of the remainder of the states having income tax laws confines its tax to one of these classes of income, there is no uniformity among them as to the concept followed.

It is unlikely that all or any considerable number of the states which follow both concepts will be sufficiently impressed with the superior merits of either to accept the loss of revenue incident to the adoption of one to the exclusion of the other. It is even more unlikely that all the states will uniformly agree that one rather than the other should be adopted. Accordingly, if discriminatory application of state income tax laws to persons who derive all or a portion of their income from sources within states of which they are not residents is to be avoided, some more practical method than arguing that states should uniformly follow one or the other concept must be found.

A number of states have attenupted to solve the double taxation dilemma by allowing either residents, nonresidents or both a credit against the tax imposed by them on income taxable under their laws for taxes imposed by other states on the same income. In so far as the elimination of double state taxation of income is concerned, it is immaterial whether residents are allowed a credit against taxes imposed by the state of residence on incoine from extraterritorial sources for taxes on the same income imposed by the state or states from which the income is derived, or whether nonresidents are allowed a credit against the taxes on income from sources within the state for taxes imposed by the state of residence on such income. If either method were adopted in all the states having income tax laws, double taxation of mcome resulting fron the taxation of residents on income from extraterritorial sources, and of nonresidents on income from sources within the taxing state, would be completely avoided.

If the credit were allowed residents, the tax imposed by the state 
of residence on income from extraterritorial sources would be extinguished by the credit in all cases where the taxes imposed by the states from which the income is derived equals or exceeds the tax imposed on such income by the state of residence. Thus the income would actually be taxed only by the states from which the income is derived. If the taxes imposed by such states are less than the tax imposed by the state of residence, the latter tax, although not extinguished by the credit, would nevertheless be reduced to the extent of the taxes imposed by the states from which the income is derived. Although taxes would be payable to two states on the same income, the total taxes would not exceed the tax that would be payable to the state of residence if that state alone taxed the income. Hence, there would be no discriminatory double taxation of the same income.

If, on the other hand, credit were allowed nonresidents, rather than residents, similar results would obtain. If the tax imposed by the state of residence on income derived from sources within another state equals or exceeds the tax imposed by that state on such income, the tax imposed by that state would be extinguished by the credit allowed for the tax imposed by the state of residence. If the tax imposed by the state of nonresidence exceeded the tax imposed by the state of residence on the income taxable in both states, the tax of the former state would be reduced by the credit in an amount equivalent to the tax imposed by the latter. Thus the taxes payable to the two states after the allowance of the credit would not exceed the tax that would be payable to the state of nonresidence if that state alone taxed the income.

Although either system, if adopted uniformly by all the states, would eliminate double taxation of income resulting from the states following both the rule of Shaffer v. Carter and the rules of Lavrence v. State Tax Commission ${ }^{7}$ and Cohn v. Graves, ${ }^{8}$ so long as some states adopt one system and some the other, discriminatory multiple taxation of the same income will still exist. Thus, if some states allow residents a credit for taxes imposed by other states and some allow nonresidents a credit for taxes imposed by the state of residence, residents of the latter deriving income from sources within the former will not be entitled to credit in either state. Hence they will be subject to discriminatory double taxation on such income. Furthermore, an extremely confusing and perplexing problem is presented in apply-

7 Supra note 2.

8 Ibid. 
ing the credit provisions of the two groups of states to residents of the former deriving incoine from the latter group. For example, suppose state $X$ allows the credit to residents and state $Y$ to nonresidents. Suppose further that $A$, a resident of state $X$, derives a net income of $\$ 20,000$ from sources in state $Y$ and that the tax imposed by each state on such income amounts to $\$ 1,000$. If each state allows a credit for taxes imposed by the other before any deduction for credit allowed by the other is inade, $A$ will be entitled to a credit of $\$ 1,000$ in each, that is, the ainount of tax imposed by the other, and thus actually will not be required to pay any tax to either state.

If it is attempted to limit the credit in each state to the tax actually owing to the other state over and above the amount of any credit allowed under the laws of such state, an impasse will be reached. To determine the amount of credit allowed by either state it would first be necessary to determine the amount of tax owing to the other state in excess of the credit allowed. This determination could be made, of course, only by first determining the amount of credit allowed, which in turn could be ascertained only by first determining the alnount of tax owing to the first state in excess of the credit allowed by it, and so on ad infinitum.

The Gordian knot could be cut if one state allowed a credit for taxes paid or required to be paid to the other after deducting any credit allowed by that state and the other allowed a credit for taxes payable to the first state before any deduction for the credit allowed by the first state is made. As a matter of fact most states which allow residents a credit confine the credit to taxes paid to other states and, on the other hand, most states which allow credit to nonresidents allow the credit for taxes payable to the state of residence. Presumably, these provisions are based on the assumption that in case of conflict the state of nonresidence should yield to the state of residence.

These provisions would operate smoothly in the above example. Since the tax payable to state $X$, the state of residence, before making any deduction for credit allowed, is $\$ 1,000, A$ would be entitled to a credit of $\$ 1,000$ against the tax inposed by state $Y$, the state of nonresidence. Thus the tax liability of state $Y$ would be extinguished and $A$ would accordingly not be entitled to any credit agamst the tax inposed by state $X$. Hence $A$ would be required to pay the full tax imposed by that state.

Suppose, however, that the rates in state $Y$ were higher than in state $X$ and as a result the tax imposed by state $Y$ amounted to 
$\$ 2,000$. Under the above provisions $A$ would be entitled to a credit against this tax for the $\$ 1,000$ tax payable to state $X$. Thus the tax would be reduced to $\$ 1,000$. Notwithstanding the reduction, if $A$ paid $\$ 1,000$ to state $Y$, he would be entitled to a credit of $\$ 1,000$ against the tax inposed by state $X$. As a result $A$ is enabled to satisfy the taxes imposed by both states, amounting to $\$ 3,000$ by the payment of but $\$ 1,000$, whereas under any sensible application of credit provisions $A$ should be required to pay $\$ 2,000$, the amount he would have been required to pay to state $Y$ if that state alone taxed the income in question.

Limiting the credit in all cases to taxes actually paid other states is likewise unsatisfactory. Under such a limitation taxpayers would be free to determine the states to which they should make their payments. Thus, if in the first example above $A$ paid the tax imposed by state $Y$, he would be entitled to a credit in state $X$. Hence, $Y$ rather than $X$ would obtain the tax. If, on the other hand, $A$ paid the tax to state $X$, he would be entitled to a credit in state $Y$, and accordingly $X$ rather than $Y$ would obtain the tax. Any system which permits the whim and caprice of individual taxpayers rather than provisions of state laws to determine the state to which they shall be liable for taxes, seems haphazard to say the least. Furthermore, such a limitation might enable taxpayers in cases like the second example above to avoid taxation. Suppose $A$ paid the $\$ 1,000$ tax imposed by state $X$ and then claimed credit therefor against the $\$ 2,000$ tax imposed by state $Y$. After allowance of the credit there would still be a tax of $\$ 1,000$ owing to state $Y$. If $A$ paid this amount, he would be entitled to a credit in state $X$ therefor, and could accordingly quite properly claim a refund of the tax paid state $X$. $A$ would, consequently, avoid a tax of $\$ 1,000$ unless, of course, state $Y$ should happen to learn of the refund and should be in a position to cancel the credit allowed by it on account of the taxes refunded.

From the foregoing it is apparent that if multiple state taxation of income is to be avoided satisfactorily through adoption of a system of credits, it is necessary that persons who derive income from sources within a state other than their state of residence be allowed a credit by one or the other of such states, but not by both. These conditions wonld be met if all the states having income tax laws uniformly allowed a credit to either residents or nonresidents. Attainment of uniformity, however, necessarily requires that the states choose between these methods. 
Each method, if adopted umiformly, will satisfactorily accomplish the desired objective. Although each entails administrative difficulties, there is no difference between them in this respect. The adoption of either may involve considerable revenue loss. The adoption of one rather than the other will affect different states differently.

If, as indicated above, a state personal income tax is primarily a means of forcing a state's residents to contribute to the costs of its government in proportion to their ability to pay, and if extension of the tax to income of nonresidents from sources within the state is justified as a means of preventing discrimination against local income of residents pending the taxation of such income of nonresidents at equal or greater rates by their state of residence, it follows that efforts to obtain uniformity in the method of allowing credits should be directed toward limiting the credit to nonresidents. Several states which tax income of both residents and nonresidents at present confine the credit to nonresidents, ${ }^{9}$ whereas only one state confines the credit to residents. ${ }^{10}$ Although a number of states allow credit both to residents and nonresidents, ${ }^{11}$ the fact that nonresidents are allowed a credit for taxes "payable" to the state of residence whereas the credit allowed residents is confined to taxes "paid" other states, suggests that these states are in accord with the principle that the state of nonresidence should yield to the state of residence. These states presumably allow their residents a credit for taxes paid other states only for the purpose of protecting them against the possibility of multiple taxation resulting from the failure of some states to recognize this principle. Accordingly, it would seem that there is greater likelihood of obtaining substantial uniformity among the states through the allowance of a credit for nonresidents than through the allowance of a credit for residents.

It is probable, however, that a number of the states, either because they are unwilling to forego the revenue which would be lost

9 The following states tax individual incomes and allow credit only to nonresidents for taxes imposed by the state of residence:

Iowa [IowA CoDE (1939) $\$ \$ 6943.036-6943.063$ ]; New York [N. Y. TAX LAW (1937) bk. 59, art. 16, § 363]; South Carolina [S. C. CoDe (1932) § 2439]; West Virginia [W. VA. Acrs (1935) c. 89, §34].

10 Kansas [Kan. Gen. Stat. Ann. (Corrick, 1935) c. 79, art. 32, § 79-3232 as amended by Kan. Laws 1937, c. 371, § 6].

11 The following states allow credit to both residents and nonresidents for taxes imposed by other states:

Cahfornia [Cax. Gen. Laws (1937) act 8494, § 25]; Alabama [ATa. Gen. Laws (1935) $\$ \S 345.15,345.16]$; New Mexico [N. M. STAT. ANN. (Courtright, Supp. 1938) $\$ \$ 141-1524,141-1525]$; Virginia [VA. TAx CODE (Michie, 1936) $\$ \$ 39,40]$. 
if they allowed nonresidents a credit for taxes imposed by the state of residence, or because they are indifferent to the problem of double state taxation of income, will fail to coöperate effectively in obtaining the desired uniformity. In any event it is unlikely that even substantial uniformity will be attained in the near future.

In the ineantime the states that are willing to coöperate in eliminating double state taxation of income through allowance of credit to nonresidents are immediately confronted with the problen of protecting their residents against double taxation of income derived from sources within states which tax income of nonresidents, but do not allow thein a credit for taxes imposed by the state of residence. There is the further problen of avoiding the confusion and perplexities incident to the application of nonresident credit provisions to those nonresidents whose home states allow them a credit for taxes inposed by the states fronl which their income is derived.

The first problenı cannot be lightly dismissed on the ground that it is an unfortunate consequence of the failure of some states to cooperate which will be avoided when uniformity among the states as to credit provisions is obtained. The necessary unanimity is apt to be a long time in coming. Pending such unanimity, it is no adequate answer to a state's residents to advise them to seek relief from double taxation by urging the states from which they derive incoine to allow thein a credit for taxes imposed by their state of residence. States which insure nonresidents against discriminatory double taxation without affording the same protection to their residents are suggestive of parents who look after their neighbor's children but not their own.

A simple solution to the problem would be to allow residents as well as nonresidents a credit. If, however, the credit is allowed irrespective of whether other states allow credit to nonresidents, an utterly chaotic condition will exist in the case of residents who derive income from states that allow credit to nonresidents. Accordingly, if residents are to be allowed a credit, the credit should be confined to taxes iniposed by other states which do not allow credit to nonresidents.

Such a limited resident credit should effectuate the purpose of protecting residents from discriminatory multiple taxation pending the adoption by the states of nonresident credit provisions, and without entailing confusing consequences. Residents deriving income from states which do not allow nonresidents a credit would be en- 
titled to credit against the tax imposed by the state of residence for the taxes imposed by such other states on such income and hence would not be doubly taxed thereon. On the other hand, by virtue of the limitation, residents would not be entitled to credit for taxes imposed by states which allow nonresidents a credit, and hence no conflict would arise in the application of the respective credit provisions. Furthernore, by virtue of the limitation, resident 'credit provisions would automatically become inoperative if all the states adopted nonresident credit provisions. Hence, allowance of such a limited credit to residents should not impede efforts to obtain unammous state recognition of the principle that the state of nonresidence should yield to the state of residence.

The second problem mentioned above, that of avoiding the confusion incident to the application of nonresident credit provisions in cases where the state of residence of the nonresident allows credit to its residents, irrespective of whether they are entitled to credit in the states where the income is earned, can be met by denying nonresidents credit for taxes imposed by their state of residence in such cases. Such an exception, of course, would not be necessary if all the states which allow residents credit for taxes imposed by other states confined the credit, as suggested above, to taxes imposed by states which do not allow nonresidents credit for taxes imposed by the state of residence. Since, however, a number of states now allow their residents credit, irrespective of whether they are entitled to credit under the laws of other states, and since it is always uncertain what the states may do in the future, it is essential that the states having or adopting nonresident credit provisions, provide for the above exception in order to insure harmonious and sensible application of such provisions.

With the foregoing limitations, a state which taxes the income of residents from both local and extraterritorial sources, and the income of nonresidents from sources within the state, but adopts both resident and nonresident credit provisions will insure the following results:

As a result of taxing the income of residents from extraterritorial sources, discrimination against residents who derive all their income from within the state will be avoided. Graduated rate provisions will apply in an equitable manner. Furthermore, the tax in all cases will be based on total net income, and thus will accurately measure ability to pay. As a result of taxing the income of nonresidents 
from sources within the state, discrimination against the local income of residents will be prevented, pending the taxation of such income of nonresidents at equal or greater rates by the state of residence.

By allowing residents credit for taxes paid other states, the state will protect residents who derive incoine froin extraterritorial sources against discriminatory multiple taxation. This will be true even if the states from which the income is derived tax such income and do not allow nonresidents credit for taxes imposed by the state of residence. As a result of allowing nonresidents credit for taxes imposed by the state of residence, nonresidents will be protected against discriminatory multiple taxation, even if the state of residence taxes income of residents from extraterritorial sources, and allows no credit for taxes imposed by the states from which the income is derived.

By not giving residents credit for taxes paid to other states if such other states allow nonresidents credit for taxes imposed by the state of residence, and by not allowing nonresidents credit if the state of residence allows its residents credit for taxes imposed by the states from which the income is derived, irrespective of whether such states allow credit for taxes imposed by the state of residence, the respective states will avoid conflicts in the application of their credit provisions.

Virtually all of the states which allow nonresidents credit do so on condition that the state of residence either not tax nonresidents, or allow them a credit for taxes imposed by their state of residence. This limitation is probably inspired by reluctance on the part of a state to be generous to the residents of another state unless that state is willing to be equally generous to the residents of the first state. It may also have been calculated to assist in obtaining uniformity among the states by encouraging states to adopt nonresident credit provisions in order that their residents might obtain the benefit of similar provisions in other states. The limitation may be employed to achieve another purpose with more immediate consequences.

Adoption by any state of both resident and nonresident credit provisions, as suggested above, may be objected to on the grounds that the state will yield both in the case of residents and nonresidents, to states which allow credit to neither residents nor nonresidents. Thus, suppose state $X$ allows credit to both residents and nonresidents, and state $Y$ to neither. The taxes imposed by state $X$ on income of its residents, derived from sources in state $Y$, will either be extinguished entirely, or reduced by the amount of taxes imposed by state $Y$ on such income. The taxes imposed by $X$ on income of resi- 
dents of state $Y$, derived from sources in state $X$, will likewise either be extimguished entirely, or reduced by the taxes imposed by state $Y$ on the same income. Thus the price of avoiding discriminatory double taxation, for which each state is equally responsible, will be paid by $X$ in both instances.

Adoption of the above limitation will avoid this objectionable result. Although states having this limitation will yield to some states in the case of nonresidents and to others in the case of residents, they will not yield to any state in the case of both residents and nonresidents. Nonresidents whose state of residence taxes income of residents from extraterritorial sources and also taxes income of nonresidents from local sources, but fails to allow credit to either residents or nonresidents, will be subject to double taxation. The other income tax states of the Union may quite properly insist, however, that such individuals should seek relief only from their state of residence by urging such state to adopt a more coöperative attitude.

At the present time many states which either tax income of residents from extraterritorial sources or income of nonresidents from local sources, or both, make no provision whatsoever for eliminating double taxation through allowance of credit for taxes imposed by other states. ${ }^{12}$ Furthermore, the credit provisions of the states which allow credit are as a general rule wholly inadequate. In most instances they were apparently drafted without any awareness of the problems discussed herein and, as a consequence, must inevitably give rise to a host of difficulties.

The credit provisions of the Califorma law, ${ }^{13}$ which were care-

12 The following states fall in this category: Arizona, Arkansas, Delaware, Idaho, Louisiana, Massachusetts, Minnesota, Mississippi, Montana, New Hampshire, North Carolina, North Dakota, Oklahoma, Oregon, South Dakota, Tennessee, Utah, Vermont, Wisconsin.

13 Cax. Personal Inc. Tax Act (1935) $\$ \S 25$ (a) and (b), as anended by Cal. Stats. 1937, p. 1855, read as follows:

"(a) Subject to the following conditions, residents of this State shall be allowed a credit against the taxes imposed by this act for net income taxes imposed by and paid to another State or country on incoine taxable under this act:

"(1) The credit shall be allowed only for taxes paid to such other State or country on income derived from sources withm such State or country which is taxable under the laws of such State or country irrespective of the residence or domicil of the recipient;

"(2) The credit shall not be allowed if such other State or country allows residents of this State a credit against the taxes imposed by such State or country for taxes paid or payable under this act;

"(3) The credit shall not exceed such proportion of the tax payable under 
fully drafted to meet the foregoing problems, are a striking exception to the general rule. They may well serve as a pattern for other states to follow.

this act as the income subject to tax in such other State or country and also taxable under this act bears to the taxpayer's entire income upon wbich the tax is imposed by this act."

"(b) Subject to the following conditions, nonresidents of this State shall be allowed a credit against the taxes imposed by this act for net income taxes imposed by and paid to the State or country of residence on income taxable under this act:

"(1) The credit shall he allowed only if the State or country of residence either does not tax income of residents of this State derived from sources within such State or country or allows residents of this State a credit against the taxes imposed by such State or country on such incoune for taxes paid or payable thereon under this act;

"(2) The credit shall not be allowed for taxes paid to a State or country which allows its residents a credit against the taxes imposed by such State or country for income taxes paid or payable under this act, irrespective of whether its residents are allowed a credit against the taxes imposed by this act for income taxes paid to such State or country;

"(3) Credit shall be allowed only for such proportion of the taxes paid to the State or country of residence as the income taxable under this act and also subject to tax in the State or country of residence bears to the entire income upon which the taxes paid to the State or country of residence are imposed;

"(4) The credit shall not exceed such proportion of the tax payable under this act as the income subject to tax in the State or country of residence and also taxable under this act bears to the entire income taxable under this act."

Although generally California allows its residents credit for taxes paid other states on income from sources in such states, and thereby protects its residents against any possibility of double taxation, under paragraph (2) of section 25(a), the credit is denied in the case of taxes paid states which allow nonresidents credit. Without this provision a chaotic situation would exist in those instances where a California resident derives income from sources in another state which taxes such income but which allows credit for taxes paid or payable to the state of residence. With this provision there can be no conflict of credit provisions in such cases, since under it the Cahifornia resident who is entitled to credit his California tax against the tax of the state where the income is earned is quite properly denied any credit against the California tax for the tax of the other state.

California, as a general rule, likewise allows credit against its tax for taxes paid by nonresidents to their state of residence on income taxable in both states. There are, however, two important exceptions. Under section 25(b)(1) credit is denied if the taxpayer's state of residence taxes income of California residents from sources within such state and fails to reciprocate by allowing credit against its tax for the California tax. Under section $25(\mathrm{~b})(2)$ credit is denied if the taxpayer is able to obtain relief from double taxation hy crediting the California tax against the tax of his state of residence. If, bowever, that state either does not allow credit to its residents under any circumstances, or as under section 25(a) of the California law denies credit if credit can be obtaimed in the state from which the income is derived, then credit is allowable under the California act. 


\section{WHO SHOULD BE TAXED AS RESTENTS?}

Domicil, long a star in the inheritance and estate tax field, also plays an important role in the field of state income taxation. In several state income tax laws the term "resident" includes only persons domiciled within the state. ${ }^{14}$ Although in most states the term includes other individuals, such as those who maintain a permanent place of abode within the state or spend a specified length of timecommonly six or seven months-therem, it also includes anyone domiciled in the state. ${ }^{15}$

Domicil itself clearly affords a constitutional basis of jurisdiction for the inposition of state income taxes. ${ }^{16}$ But the extent to which the states should, as a matter of policy, rely on domicil as a standard for determining who are taxable only on local income and who are taxable on their entire income, including income from intangibles and income from extraterritorial sources, is open to serious question.

Since a domicil once acquired is retained until a new one is acquired in another state, the acquisition of which requires not only actual presence there, but, in addition, an intention to make one's permanent home therem, coupled with an intention to abandon the

14 Arizona [ARIz. CODE (1939) § 75-1504(d)]; Massachusetts [MASs. ANN. LAwS (Michie, 1933) c. 62, § 25]; Minnesota [MInN. Stat. (Mason, Supp. 1936) § 2394-1(f)]; NEw Mextco [N. M. Stat. ANN. (Courtright, Supp. 1938) § 141-1503(m)]. See also DEL. REv. CODE (1935) §144(b), defining a "taxable" as a citizen or resident.

15 In the following states "resident" includes anyone douniciled in the state and, in addition, anyone who ineets the conditions indicated helow:

Alabama [ALA. GEN. LAws (1935) §345.1(b), maintains permanent place of abode or spends in the aggregate more than seven months of the year in state]; Arkansas [ARk. Dig. Stat. (Pope, 1937) § 14025(9), same as Alabama, except six months substituted for seven]; Colorado [Colo. Laws 1937, c. 175, § 1(9), same as Arkansas]; Georgia [GA. CoDE (1933) \$92-3002(i), has place of abode and spends in the aggregate four months of year in state]; Iowa [Iowa CoDE (1939) $\$ 6943.036(8)$, same as Arkansas]; Kansas [KaN. GeN. StaT. ANN. (Corrick, 1935) § 79-3202(9), maintenance of permanent place of abode and aggregate of more than six months of year spent in state]; Louisiana [LA. Gen. Stat. AnN. (Dart, 1939) § 8587.1, same as Arkansas]; Maryland [Md. Laws 1937, c. 11, $\S 215(\mathrm{~h})$, maintenance of place of abode $\mathrm{m}$ state for more than six months of year] ; Montana [MoNt. Rev. Cones ANN. (Anderson \& McFarland, 1935) $\S 2295.1(6)$, same as Kansas, except seven months substituted for six]; North Dakota [N. D. CoMr. Laws Anv. (Supp. 1925) § 2346 a, I (10), same as Montana]; Oklahoma [OKLA. Stat. (Harlow, Supp. 1936) §12498 d(j), same as Montana]; Oregon [ORE. Cosip. Laws (1940) $\$ 110-1602(7)$, same as Montana]; South Dakota [S. D. CoDE (1939) § 57.2601 (11), same as Arkansas]; Utah [UTAE REv. STAT. (1933) § 80-14-1(7), same as Kansas]; Virginia [VA. TAx CoDe (Michie, 1936) §23, same as Maryland]; Wisconsin [Wisc. Stat. (1937) c. 71, § 71.01, same as Alabama].

${ }^{16}$ See New York ex rel. Cohn v. Graves and Lawrence v. State Tax Comm., both supra note 2. 
former home, and since the domicil of a married woman is usually the same as that of the husband, and the domicil of minor children, regardless of where born or where they live, is that of their parents, it is clear that one need not live within a state to be domiciled therein. Conversely, one may live within a state for a number of years without being domiciled there. Although generally domicil and residence coincide, instances of persons being domiciled in one state while residing in another are by no means infrequent. ${ }^{17}$

To tax the entire income of a person who was not in the state during the tax year, nor possibly for many years, simply because he is domiciled therein, and to exempt a person who actually resides within the state, enjoying the benefit and protection of its laws and government, from the obligation of making a contribution to the cost of such government based on his total income, simply because he does not intend to make his home there indefinitely or has not abandoned his previous home, appears arbitrary and capricious. Furthermore, since domicil depends so largely on one's intention, the practical difficulties of discrediting claims, inspired in many instances possibly by a desire to avoid taxation, of domicil outside the state,

17 Eaves Costume Co. v. Pratt (1893) 2 Misc. 420, 22 N. Y. Supp. 74, individual who lived in New York for two years prior to death held domiciled in Missouri; Moorhouse v. Lord (1863) 10 E. L. 272, individual who lived last six years of life in Paris held domiciled in Scotland; Winans v. Attorney General [1904] A. C. 287, Amcrican engineer who went to Russia at age 27, stayed there for 9 years, then moved to England where he lived for 34 years until death, except for frequent visits to Russia, held domiciled in United States; Dupuy v. Wurtz (1873) 53 N. X. 556, woman held domiciled in New York at death although for last 12 years of life had lived ahroad; Gould v. Gould (1923) 235 N.Y. 14, 138 N. E. 490, husband and wife who were married in Paris, lived there six years, held domiciled in New York; Harris v. Harris (1927) 205 Iowa 108, 215 N.W. 661, held individual retained domicil he had when he joined army, although served for 35 years and was stationed at various posts; Jopp v. Wood (1865) $4 \mathrm{De}$ G. J. \& S. 616, held individual retained domicil in Scotland, although he had resided in India for busmess purposes for many years; Grant v. Grant (1931) Scors L. T. 180, child born in India held domiciled in Scotland although father and grandfather had lived in India most of their lives; Capdevielle v. Capdevielle (1869) 21 LAw Trares N.S. 660, Frenchman who lived in England for 20 years, held not domiciled there.

The foregoing are only a few cases where individuals have been held domiciled in a particular state or country, although absent therefrom for long periods of time. Many similar cases can be found. The Franchise Tax Commissioner's office which administers the California Personal Income Tax Act frequently encounters the contention that wealthy individuals who have hived in the state for years are nevertheless not domiciled therein. Many of such individuals doubtlessly would eseape taxation by the state on all or a large part of their income if extraterritorial income and income from intangihles were taxable only in the case of individuals domiciled in the state. For the definition of "resident" in the California Act, see infra note 28. 
superable. Furthermore, the tax could be avoided by the taxpayer's arranging to be absent from the state at the time income in any sizeable amount was to be received. Requiring taxpayers to report incoine accrued during their presence in the state, even though received while absent from the state, would afford only a partial solution inasinuch as the tax on certain classes of income, such as dividends, conld still be avoided by being absent from the state when the dividends are declared and paid. Furthermore, this reinedy would involve abandonment of the cash receipts and disbursements inethod of reporting income which is peculiarly adapted to individual taxpayers who either cannot or will not keep the accounts necessary for reporting on the accrual basis.

These difficulties could be avoided by providing that, if the taxpayer spent in the aggregate the prescribed length of time in the state during the taxable year, he should be taxable upon his entire income for that year. If such a provision were adopted, the prescribed period of time should be inore than half the taxable year, for otherwise it would be possible for taxpayers to be in more than one state for the prescribed length of time during the taxable year and hence taxable in more than one state upon their entire incoine for the year.

Under such a provision, not only would persons whose stay within the state is broken be taxable upon income received and accrued during the interval when absent from the state, but income received and accrued during the portion of the taxable year before a person came in the state, as well as income received and accrued during the portion of the taxable year remaining after a person left the state, would likewise be taxable.

In all three of these cases the tax would apply to income received and accrued during a period in which the taxing state was without jurisdiction to tax the recipient thereof. Thus, this rule presents not only the question whether presence of the taxpayer within a state for the prescribed length of time affords a jurisdictional basis for taxing income from intangibles and extraterritorial income, but also the further question whether the period durmg which the state has jurisdiction to tax the recipient and the period during which the income is received and accrued inust coincide.

Since the taxation of income from intangibles and extraterritorial sources depends upon jurisdiction over the recipient and is founded upon the protection and benefits accorded the recipient under the laws of the taxing state, it is arguable that as applied to residents 
as well as the virtual impossibility of enforcing payment of taxes when a person is domiciled within, but resides without the state, render domicil a thoroughly impractical test of jurisdiction.

In Lawrence v. State Tax Commission the Court stated that the tax in question was "founded upon the protection afforded to the recipient of the income by the state, in his person, in his right to receive the incoine, and in his enjoyment of it when received". ${ }^{18}$ Although the Court stated that these were rights and privileges incident to domicil, these rights and privileges are not confined to persons domiciled within the state but are extended equally to all persons within its limits, whether there for temporary or permanent purposes, and regardless of their intentions as to the duration of their stay. This reasoning suggests that a state could, if it so desired, tax the income from all sources received by a person in the interval between his entrance into and departure from the state, no matter how short that interval may be. Whether or not such power exists is an academic question. Even if the administrative problem of ascertaining the persons taxable, of computing income and deductions on the basis of small fractional periods of a year and of collecting the tax once determined, could be overcome, the effect the tax would have in isolating the state by discouraging visitors from beyond its borders would prevent any state froin going to such extremes.

Taxation of persons physically present in the state for a prescribed length of time on the basis of income from all sources is also unsatisfactory. Requirement of continuous presence in the state for the prescribed period would simply result in departures from the state for the purpose of avoiding the rule by breaking the continuity of presence. Although this objection could be met by providing that the prescribed period should be based upon the aggregate rather than continuous time spent in the state during the taxable year, other seri- ! ous difficulties remain.

Imposition of the tax only upon income received or accrued while the recipient is actually in the state is administratively inexpedient. Computation of income and deductions even on the basis of annual periods presents many difficult and perplexing problems in determining the period to which the income and deductions are attributable. But the obstacles to apportioning incoine and deductions to the days, weeks or months the taxpayer happens to be within the state are in-

${ }^{18}$ Supra note 2, at 281. A similar statement is made in New York ex rel. Cohn v. Graves, supra note 2, at 313 . 
and other persons within the state's jurisdiction, an income tax is either a personal tax or a tax for the privilege of enjoying the protection and benefits of the laws of that state.

Accordingly, if in the case of persons subject to the state's taxing jurisdiction, income itself is not taxed but is simply the measure or standard fixed for determining the amount of the tax, the alnount of income considered, although directly affecting the amount of tax, can have no bearing on the state's jurisdiction to impose the tax. Thus it is arguable that just as the state has jurisdiction to exact a tax from residents even though income from extraterritorial sources is considered in determining the amount of the tax, so the state likewise may tax an individual within its jurisdiction at some time during the year, even though income received and accrued during a period the recipient was not within the jurisdiction of the taxing state is considered.

In other words, since income itself is not taxed, but is relevant only in determining the amount of the tax imposed on a person or privilege within the state's jurisdiction, there is no necessity that the period during which the income is received and accrued should coincide with the period during which the state has jurisdiction over the person or privilege taxed. Thus, if a state provides that income for a twelve inonth period is the measure of the ainount that persons enjoying the benefit and protection of its laws at any time during that period must pay, the fact that the taxpayer was not within the state during the whole of that twelve month period is immaterial.

On the other hand, it may be contended that to require all persons who are within the state for the specified length of time during the taxable year to pay a tax based on the entire income for that year. would result in denying persons who are within the state for less than the full year the equal protection of the laws. Thus, taxpayers who are in the state for only six months and who, accordingly, enjoy the protection and benefits accorded by the state for only six inonths would be required to pay a tax based on income for the same period of time as persons who are in the state during the entire year and who enjoy the protection and benefits of its laws for a period twice as long. If an income tax as applied to residents is based on the protection and benefits accorded the recipient of the income, and if the income measures the amount to be paid therefor, it would seem that, if the tax is to apply equally, it must be measured by income for the same length of time as the period for which the protection and benefits are conferred. 
Furthermore, in the case of income from intangibles and extraterritorial sources received and accrued during a period the recipient is not within the jurisdiction of the state, there is no relationship between the income and any benefits or services conferred by the taxing state. It may be held, accordingly, that to base a tax on such mcome is so arbitrary and unreasonable as to constitute a deprivation of property without due process of law.

There are other serious objections to taxing the income of the entire taxable year of persons who spend more than half but less than the entire year in the state. Such a provision would induce taxpayers with sizable incomes to keep a scrupulous record of the hours spent within the state and to depart therefrom before the lapse of the prescribed period. Furthermore, it might frequently happen that a taxpayer would not spend more than half the taxable year in any state, and accordingly would not be taxed in any state as a resident.

Most serious of all, however, under such a provision, a person whose stay within the state for the prescribed period happened to fall within his taxable year would be taxable upon his entire income for that year, whereas another person, although present within the state for an equal or even greater length of time within a twelve month period, but whose stay fell partly in one taxable year and partly in the succeeding year might not be within the state for the prescribed period in either year, and hence would not be taxable as a resident in either year. Thus, rank discrimination would result between taxpayers depending solely on the fortuitous circumstance of when they happened to be within the state. To provide that any taxpayer who is in the state for the prescribed length of time in any twelve inonth period should be taxable on his entire income for that period would be no remedy, since it would be impossible to fix with certainty the commencement and termination of the twelve month period, or to prevent an overlapping of the taxable periods in the various states.

A number of states provide that a person maintaining a place of abode, or a pernianent place of abode within their limits, is a resident thereof, subject to taxation upon their income from all sources. ${ }^{10}$ If jurisdiction to tax mcome from extraterritorial sources is founded upon the protection afforded the recipient in his person and in his right to receive and enjoy the income, a tax on income from such sources based simply on the maintenance of a place of abode un-

19 Kentucky, Maryland, Mississippi, Virginia. For citations to laws see supra note 15. 
accompanied by domicil or presence within the state would be clearly invalid. Generally a person having a place of abode within the state will be present therein for at least a portion of the year. Accordingly, jurisdiction to tax his entire income might possibly be upheld on that ground. It is common knowledge, however, that many people maintain places of abode in several states, and it may happen that they may not occupy one or more of such places during a taxable year. Even if they should be present in each of such states sometime during the year, the possibilities of multiple taxation are apparent.

Another possible solution of the problem of determining the proper basis for the taxation of income from intangibles and income from extraterritorial sources is to base the tax upon residence within the state for other than temporary or transitory purposes. As used in the federal revenue act providing for the taxation of income from all sources of resident aliens ${ }^{20}$ the term has been held to include all aliens present in the United States for other than a transitory or temporary purpose. Thus, in Bowring v. Bowers, ${ }^{21}$ the court declared:

"An alien actually present in the United States who is not a mere
transient or sojourner is a resident of the United States for the pur-
poses of the mcome tax. Whether he is a transient or not is deter-
mined by his intentions with regard to the length and nature of his
stay. A mere floating intention, indefimite as to time, to return to
another country is not sufficient to constitute him a transient. If he
lives in the United States and has no definite intention as to his stay,
he is a resident. One who comes to the United States for a definite
purpose which in its nature may be promptly accomplished is a
transient; but if his purpose is of such a nature that an extended
stay inay be necessary for its accomphishment, and to that end the
alien makes his home temporarily in the United States, he becoines
a resident, though it may be his intention at all times to return to
his domicile abroad when the purpose for which he came has been
consummated or abandoned."

It was established as early as 1817 that the English income tax which applies to the entire income of persons residing in the United Kingdom makes residence rather than domicil the test of liability for the tax. In Attorney General v. Coote ${ }^{22}$ it was said: "The fact of the defendant's domicile has nothing to do with the question" and

20 I. R. C. $\S 11$, Reg. 103, §§ 19.11-2, 19.211-2.

21 (C. C. A. 2d, 1928) 24 F. (2d) 918, 923.

22 (1817) 4 Price 183, 187, 146 Eng. Rep. 433, 434, 435. 
further "The verdict is found on very plain facts, and I think they shew that the defendant did not reside here for a temporary purpose. The question of domicile goes beyond the case. No doubt he was domiciled in Ireland, and so he might have been if he had resided here 20 years; but the question turns on the plain language of the act, and I think the intention of the legislature quite clear." This concept was again repeated in Inland Revenue v. Cadwalader ${ }^{23}$ where the court stated: "Domicile has no bearing on the question, and where a person has in fact a residence in the United Kingdom, he is chargeable as a person residing there, although he may also have a residence, or residences, out of the United Kingdom."

An essentially similar construction has been given to Canadian statutes taxing the entire net mcoine of residents. Thus in Ottawa v. Nantel ${ }^{24}$ it was held that:

"Residence is quite distinct from domicile, and any attempt in statutes such as this to treat the words as equivalent must almost inevitably defeat the object of the statute. A foreigner may reside here many years with his wife and family, and yet retain his domicile of origin. The change of domicile depends upon the will of the individual, and no Legislature ever intended the liability to bear the burden of taxation properly attributable to residence to depend on the volition of the person to be taxed."

Residence, as thus defined, it is beheved, is a more practicable and fairer basis for income taxation than domicil. The use of domicil as a test of jurisdiction frequently results in the exemption of the income of persons who, although domiciled elsewhere, live in the state year after year obtaining the same protection and benefits of government from the state as other residents of the state who also happen to be domiciled therein. At the same time persons who remain domiciled in the state remain taxable upon their entire net inconre even though absent from the state for years enjoying none of the benefits or protection of its law. Enforcement of the tax will be virtually impossible in a majority of such cases. Generally the existence of such persons and the amount of their income cannot be ascertained and even if, through returns filed with the federal governinent or other sources, this information became available, there is no effective method of compelling payment of the tax except in those instances in which the taxpayer has property in the state, or dies domi-

23 (1904) 7 Sc. Sess. Cas. (5th ser.) 146, 149.

24 (1921) 51 Ont. L. Rep. 269, 276, 69 D. L. R. 427, 433. 
ciled therein leaving an estate to be distributed under the laws of such state. The New York legislature in 1935, impressed by the difficulties and inequalities resulting from the taxation of the income of persons domiciled but not residing in the state, receded from domicil as a test of jurisdiction to the extent of exempting persons who, although domiciled within the state, inaintain no permanent place of abode therein but maintain a permanent place of abode without the state and who are not within the state for more than thirty days of the taxable year. ${ }^{25}$ This amendment was made retroactive to 1919 , the year the New York income tax was adopted.

These inequitable and impractical consequences would be avoided if income taxes were based upon residence rather than domicil. All persons whose stay within the state is of such duration or for such purposes that it cannot be said to be of a temporary or transient nature would be required to contribute to the support of the state according to their income while there, irrespective of their intention sometime to depart therefrom, and in the case of married women, children and incoinpetents, irrespective of whether a domicil within the state is assigned them by operation of law. On the other hand, persons who are absent from the state, except those absent for temporary or transient purposes, would not be required to pay taxes on their income simply because of an intention sometime to return to the state or because, in the case of married women, children and incompetents, the law prevents them from changing their domicil to some other state.

It is assumed above that residence, once established in the state, is not lost by temporary absences therefrom. Residence, like domicil of choice, implies a settled, more or less permanent relationship. Residence differs from domicil of choice principally in that absence of intention to remain indefinitely or a present intention sometime to return to a former residence prevents the acquisition of a new domicil of choice but not a new residence. Acquisition of a residence, however, does require an intention to remain in a state for more or less permanent purposes. As a domicil of choice within a state is retained so long as the intention to remain there indefinitely continues, notwithstanding temporary absences therefrom, so residence, once established, is retained so long as the purpose upon which the residence is based continues, notwithstanding temporary absences therefrom.

${ }^{25}$ N. Y. TAX LAW (1937) §350(7); Alabama [AxA. GEv. LAws (1935) §345.1(6)]. 
The use of this concept of residence as the basis of jurisdiction to tax income, might be criticized on the ground that it will result in the taxation of income received and accrued during periods the recipient is absent from the state and in that respect is as objectionable as domicil as a basis of jurisdiction to tax. The use of domicil as the basis, however, may result in the taxation of income of persons absent from the state for long periods of time and who may in fact have acquired a residence elsewhere. Clearly a person cannot be considered present in the state for more or less permanent purposes, and hence a resident of such state, if he is absent from the state for a long period of time or has become a resident of some other state. Accordingly, the use of residence as a basis of income taxation does not result in the taxation of income of persons absent from the state to the extent they would be taxed if domicil were the basis of taxation.

To limit the tax in the case of residents to income received or accrued only when they are physically present within the state would not only involve great administrative difficulties in ascertaining the income and deductions attributable to the days of the taxable year a resident is within and without the state, but would also offer a convenient method of avoiding the tax by the taxpayer's arranging to be absent from the state when imcome was to be received or accrued. Furthermore, since a resident of a state temporarily absent therefrom would not become a resident of another state, such income might escape taxation entirely if residence were the basis of taxation in such other state. As a matter of fact, if income from intangibles is to be taxed at all and if income from other sources is to be taxed in any state other than the state in which derived, it must be taxed either where the person happens to be at the time of its accrual or receipt, an obviously impractical basis of taxation, or at his domicil or residence.

Although every person is always domiciled in some state, it may happen that at times one may not be in any state for other than temporary or transitory purposes and hence not be a resident of any state. In order to prevent taxpayers from escaping a tax computed upon their entire income in such instances, the states might properly rely on domicil as a basis for the imposition of income taxes to the limited extent of providing that during the time a person is not a resident of any state his income shall be taxable by the state of domicil.

Perplexing problems will unquestionably arise, particularly in the case of taxpayers who recurrently spend a portion of the year 
within the state, in determining their state of residence. These problems should prove no more difficult of solution, however, than the problems involved in the determination of the domicil of taxpayers. In fact, it should prove easier to determine one's residence than one's domicil since residence depends more upon objective considerations such as the duration of one's stay in the state, the nature of his activities therein, and less on subjective considerations such as intention. A number of states now provide that remaining in the state for a prescribed length of time or maintaining a permanent place of abode therem gives rise to a presumption of domicil. ${ }^{20}$ Such a presumption seems clearly valid. ${ }^{27}$ These facts are as much an indication of residence as they are of domicil and accordingly it would seein equally permissible to base a presumption of residence thereon which could be rebutted only by the taxpayer's proving that he was in the state for merely temporary purposes. By means of such a presumption many of the difficulties in the way of determining residence may be overcoine. ${ }^{28}$

If presence within the state is a constitutional basis for the taxation of income as indicated in Lawrence v. State Tax Commission and Cohn v. Graves, an income tax based upon residence within the

26 Arizona [ARIz. CODE ANN. (1939) § 73-1504(d)]; Massachusetts [MASs. ANN. LAws (Michie, 1933) c. 62, § 25].

27 In Mobile, J. \& K. C. R. R. v. Turnipseed (1910) 219 U. S. 35, 43, the Supreme Court stated the rule respecting the validity of presumptions as follows:

"Legislation providing that the proof of one fact shall constitute prima facie evidence of the main fact in issue is but to enact a rule of evidence, and quite within the general power of government ....

"That a legislative presumption of one fact from evidence of another may not constitute a denial of due process of law or a denial of equal protection of the law it is only essential that there shall be some rational connection between the fact proved and the ultimate fact presumed, and that the inference of one fact froin proof of another shall not be so unreasonable as to be a purely arbitrary nuandate. So, also, it must not, under guise of regulating the presentation of evidence, operate to preclude the party from the right to present his defense to the main fact thus presumed.

"If a legislative provision not unreasonable in itself prescribing a rule of evidence, in either criminal or civil cases, does not shut out from the party affected a reasonable opportunity to subnit to the jury in his defense all of the facts bearing upon the issue, there is no ground for holding that due process of law has been denied him."

28 Section 2(k) of the California Personal Income Tax Act as amended by Cal. Stats. 1937, pp. 1831, 1832, enbodies the suggestions herein made respecting the definition of "resident". This section reads as follows:

"(k) Every natural person wbo is in the State of California for other than a temporary or transitory purpose is a resident and every natural person domiciled within this State is a resident unless he is a resident withm the meaning of that terin as herein defined of soine other State, Territory or country. Every natural person who spends in the aggregate inore than nine months of the tax- 
state would certainly be valid. The validity of residence as a basis for mcome taxation, however, does not necessarily require holding that mere physical presence of the taxpayer within the state alone affords jurisdiction for such a tax. Residence implies a far more settled and substantial relationship to a state than mere physical presence therein. In fact, short of residence and domicil combined, residence is the most substantial relationship existing between a person and a state. To confine the taxation of income from intangibles and extraterritorial sources to persons both resident and domiciled in the state would unean that all persons who are domiciled in one state but residing in another would not be taxable in any state upon such imcome. Since a resident receives substantially the same benefits and advantages from the state as a person who is both resident and domiciled therein, the state should have the power to require him to bear substantially the same burden of taxation.-

Until the decision of the Supreme Court in Wheeling Steel Corporation $v . F o x,{ }^{29}$ it was generally understood that except in the case of intangibles which acquired a business situs elsewhere, intangibles owned by a corporation were taxable only at the corporation's domicil, that is, the state of incorporation. This case held, however, that intangibles owned by a corporation having its principal place of business within the state where its directors met and the principal officers were located, and where the active management and control of the business was exercised, had a situs for taxation in that state, even though the corporation was domiciled in another state. The Court stated in the course of its opinion that to hold that intangibles were taxable in the state of incorporation to the exclusion of the state where the management functioned would "make a legal fiction dominate realities".30 A legal fiction would likewise dominate realities if the jurisdiction of the state of an individual's domicil to tax his incoine from all sources were upheld to the exclusion of the state where he actually resides and from which he derives the benefits and protection of governunent.

able year within the State or maintains a permanent place of abode within this State shall be presumed to be a resident. The presumption may be overcome by satisfactory evidence tbat such person is in the State for a temporary or transitory purpose. Any natural person who is or shall become a resident of this State shall continue to be a resident even though temporarily absent from the State. Every natural person other than a resident is a nonresident."

29 (1936) 298 U.S. 193.

30 Ibid. at 211. 